\title{
Productivity and Technical Efficiency Variability among Small-Holder Cotton Farmers in Tanzania.
}

\author{
Paul Maganga Nsimbila \\ School of Business, Mzumbe University \\ P.O. Box 6, Mzumbe, Morogoro, Tanzania
}

Received: Apr. 16, 2021 Accepted: May. 26, 2021 Online published: Jun. 17, 2021

doi:10.5296/jpag.v11i2.18534 URL: https://doi.org/10.5296/jpag.v11i2.18534

\begin{abstract}
This study assessed the productivity and technical efficiency variability among small-holder cotton farmers in Bunda district, Tanzania. The efficiency analysis results have shown that the scores of technical efficiency sample of contract farmers varied from $1.75 \%$ to $87.07 \%$, with an average of $46.05 \%$. The implication of this is that there existed considerable technical deficiency in cotton farming. That is to say, usually, small-holder cotton contract farmers in the investigation region incurred loss of about $53.95 \%$ in outputs as a result of technical deficiency. The sources of inefficiency for contract farmers were experience of contract farmers, gender of household head and owning Television (TV)

On the other hand, non-contract small-holder farmers' technical efficiencies varied from $3.94 \%$ to $82.05 \%$, having a mean of $46.79 \%$. Usually, small-holder non-contract farmers in the investigation region incurred loss of about $53.21 \%$ in outputs as result of technical deficiency. The implication of this is that output average can be raised by at least $53.21 \%$ through the application of resources available as well as the given technology if the deficiency factors are addressed fully. The source of inefficiency for non-contract farmers is owning TV.

It is recommended that young farmers need to be encouraged to join contract farming in order to get high productivity, more female headed households should be encouraged to participate in contract farming, both contract and non-contract farmers should watch TV programs which are educative and can assist them gain farm management knowledge for high productivity and lastly, ginners are required to provide more services in exchange of exclusive purchasing rights as agreed when signing contracts.
\end{abstract}

Keywords: contract, contract farming, ginners, technical efficiency, contract farmers, non-contract farmers 
Contribution of the study: Despite of the fact that there are several studies that focused on cotton value chain in Tanzania, rigorous qualitative and quantitative analysis on the connection between variability of productivity and technical efficiency variability among cotton contract farmers was not available to the best of my knowledge. The efficiency analysis outcomes show that small-holder farmers were producing not only at the lowest possible level, but also performed relatively far from the production frontiers. Therefore, there was substantial room to increase productivity and output by expanding efficiency of production at the relatively ineffective farmlands as well as supporting the efficiency of farmers who work at or nearer to the frontier.

Originality of the paper: This paper is an extra from the $\mathrm{PhD}$ thesis of the author which was submitted at Mzumbe University, Tanzania.

\section{Introduction}

The significance of cotton is confirmed in that around $40 \%$ of the farmers depend on it for their livelihood. Therefore, out of 127 districts and 21 regions, cotton crop is produced in the total number of 42 districts of 13 regions. At this moment, nearly $99 \%$ of this crop is produced in Western Cotton Growing Area, with the region of Shinyanga that contributes for about $60 \%$ of the whole crop production. This is followed by Mwanza Region with the total production of about $20 \%$. However, all the rest of it $1 \%$ is produced in Eastern Cotton Growing Area. Around $95 \%$ of the cotton produced by the use of hand-hoe, on cultivation areas at an average of $1 / 2-50$ hectare in size. When considering international standards, the outputs are low due to reliance on rain fed for all cotton plantations, with limited efforts in applying improved crop and agriculture administration procedures. In excess of $70 \%$ is export-oriented in the form of raw product as lint. Besides, its minimum amount processed into is garments, yarn as well as textile materials. In early 1990s the textiles industry collapsed, mainly as a result of unfavorable tax-policy, discrimination against local producers; and the saturation of the domestic markets by imports of second-hand clothes (TCB, 2010a).

The sector of cotton, with its fundamental stakeholders ranging from 350,000- 500,000 small-holder farmers; 70 oil millers, ginners and exporters; 4 cooperative unions, 1 grower association; 21 weavers, spinners as well as textile millers; and form of government, guided by the Local Government Authorities, Tanzania Cotton Board, Ministry of Agriculture Cooperatives and Marketing, is led in the functioning by various national policy, strategy and programme frameworks, such as Millennium Development Goals; Agriculture Sector Policy, Strategy and Programme; Vision 2025; Kilimo Kwanza; and MKUKUTA (TCB, 2010c; URT, 2016). All policies, strategies, programs and initiative aim at increasing productivity of small-holder farmers.

There is a widespread acceptance that a long-term economic growth is influenced by productivity promotion as well as growth of output in the agricultural, especially among small scale farmers. Empirical observation point-out that small-scale farms are useful not just that they minimize the unemployment rate, as that is not enough, they offer greater equality of income distribution and also act as an efficient demand structure for the economy of other sectors (Bravo-Ureta \& Pinheiro, 1993, 1997 cited in Poudel et al, 2011). As a result, several 
researchers and policy-makers directed their focus on the impacts of the implementation of modern technologies could have on crop yield and revenue (Hayami \& Ruttan, 1985; Kuznets, 1966 cited in Thiam, Bravo-Ureta, Teodoro, 2001). Nevertheless, in the past decade, main technological advancements resulting from the green revolution became successful throughout the developing countries. This implies that attention to improved productivity resulting from better utilization of present state technology is justified (Bravo-Ureta and Pinheiro, 1993, 1997; Squires \& Tabor, 1991 cited in Poudel et al, 2011).

The availability of efficiency shortfalls relates to the fact that production can be improved without the requirement of extra normal inputs as well as without the requirement for the application of advanced technologies. If this happens, then it is important to use efficiency empirical measures for the purpose of determining the gain's magnitude which could be attained through production performance improvement along with a particular technology (Chirwa \& Dorward, 2014). Policy implication resulting from significant degree of inefficiency is that, it could be less expensive to attain short-run increments in agricultural production as well as revenue. This can be achieved by focusing on increasing effectiveness rather than relying on introduction of modern technologies (Binam, Tonye, \& Wandji, 2005; Roco et al, 2017; Lebailly et al, 2018; Khan et al, 2017).

Gul et al., (2009) and Mburu et al (2014) argue that factors highly influencing farmers' efficiency level revealed to be age of farmers, level of education as well as groups of cotton production regions while Msuya, Hisano and Nariu (2008) found that Low education levels, inadequacy extension services, scarce funds, fragmentation of land, as well as non-availability and input high prices are revealed to have an adverse impact on technical competence. Small-holder farmers employing hand hoe and those having cash revenues apart from their farm interests (petty business) are discovered to be more successful. Nevertheless, farmers who utilize agro-chemicals are discovered to be less successful.

In Tanzania, there are few empirical works which have been carried out to study quantitatively productivity and efficiency standards of small-holder cotton farmers aiming at identification of ways and means of enhancing their effectiveness after contract farming. Therefore, policy formulation and improvement on cotton contract farming can be hindered by inadequacy of closely connected empirical researches in the farms. In such a way, this study assessed the productivity and technical efficiency of small-holder cotton producers with and without contract farming in Bunda District and identified factors that cause technical inefficiency by examining the relationship between efficiency level and possible factors.

\section{Materials and Methods}

\subsection{Analytic Framework on Productivity and Technical Efficiency}

Involvement in progressive supply-chain could influence choice of farmers relating to technology of production. For example, precise demands with regard to, food safety, quality and consistency in delivery may require the application of better seeds, reliable irrigation equipment, as well as other advanced inputs. Simultaneously, assurance of market may also improve the ability and willingness of farmers on investing in technological innovations. 
Involvement in progressive supply-chains could also affect positively Technical Efficiency, since it provides output and sales related information. This is specifically so in situations where agri-business firms offer contract farmers extension services (e.g., Masakure \& Henson 2005; Schipmann \& Qaim 2010 cited in Rao et al., 2012). For other situations, development organizations might be engaged in connecting small-holder farmers to high value markets by means of technical as well as institutional assistance (e.g., Ngugi, Gitau, \& Nyoro 2007). And eventually, ensured markets as well as greater stability on prices in progressive supply-chains (Michelson, Reardon \& Perez, 2012) may entail gains in Scale Efficiency.

Hence, various studies have been using different analytical models to analyse the impact of adoption of new technology on productivity and technical efficiency. For example, Hayami and Ruttan (1985); Abri and Mahmoudzadeh (2015) used the meta-production function concept like an envelope of neoclassical production functions in the analysis of impact adoption of modern technology. This presupposes that, farmers in traditional channels and supermarkets work using various technologies of production that are expressed by the way of group specific frontiers. Battese, Rao, and O'Donnell (2004) and O'Donnell, Rao, and Battese (2008) created Meta Frontier (MF) model, which allows technology gaps' estimation for producers using various technologies with respect to the potential technology accessible to the overall production industry.

In this study, we focus on technical Efficiency in determining a measure of individual farmer's performance in agricultural production. From the analysis of this study, the measurement of output is based on aggregate kilograms of cotton produced. Cotton is the major cash crop in the study area and it is often planted alone, in rare cases; it might be jointly planted with maize. As inputs, we include Total labor (TL), Total pesticides used in bottles or acre packs (TP), Total capital employed (TCA), Total Seed used in kilograms (TS) and Total Land cultivated for cotton (TLD), because all these are key inputs of operating systems of agriculture in Tanzania. Labor is constructed from aggregate number of man-days for activities of production, comprising preparation of land, plantations, weeding as well as harvesting. Cotton cultivated area was used for the land variable. Total pesticides used is measured in bottles or acre packs because there are many varieties of pesticides used for pest control in the study area with varying volumes such $50 \mathrm{cc}, 70 \mathrm{cc}, 100 \mathrm{cc}, 200 \mathrm{cc}$ but regardless of their varying volumes, all of them are mixed with 20 litres of water. A stochastic frontier model is applied as it has the benefit of segregating random noise from the component of productivity (see Kumbhakar \& Lovell, 2000).

\subsection{Model Specification on Productivity and Technical Efficiency}

The stochastic frontier production model suggested by Battese and Coelli (1995), Coelli et al., (1998) in compliance with the earliest models of Aigner, Lovell and Schmidt (1977); and Meeusen and van den Broeck (1977) is used to cross-sectional data for the purpose of determining the cotton small-holder famers' production efficiency in Bunda. This study defined inefficiency as interval between the actual cotton production quantities of a farm and the projected frontier cotton production quantity corresponding to the situation of its 
technology for producing.

The researcher considers the stochastic frontier approach as it is suitable for record accurately error of measurement as well as different statistical noise affecting the position and shape of the production frontier. The technique responds more effectively to an agricultural production that is considerably affected by exogenous-shocks randomly like that one discovered in Tanzania. This technique presupposes that, producers might diverge from the frontier not simply because of statistical noise, measurement errors or any unsystematic effect, just as well because of technical ineffectiveness. Output quantity in kilograms was applied as the response variable, with the assumption that there is a perfect competition on market structure.

In this study, one-stage approach was employed to forecast the inefficiencies and the reasons associated to them. The model involved independent variables applied to describe efficiency when estimating the technical efficiency measures. The results of the prospect ratio type experiment, applied to test Cobb-Douglas model contrary to the translog, indicated this model was suitable to be applied for the data. Thus, there was no convergence results obtained from estimating technical using translog.

According to Msuya and Ashimogo (2005) hence stochastic frontier production models have been suggested by Aigner, Lovell and Schmidt (1977) and Meeusen and van den Broeck (1977). Their globally applications in literature are extremely high. Battese and Coelli (1995) suggested a stochastic frontier production function, whereby it has strong impacts presumed to be distributed as a normal random variable, by doing that, impacts of inefficiency are influenced directly by several variables. Considering the objective of research, the two groups of farmers in a summarized stochastic frontier model can be expressed in the following way:

$\operatorname{lnOutput}=\beta_{\mathrm{o}}+\beta_{1} \ln \mathrm{TLD}+\beta_{2} \ln \mathrm{TL}+\beta_{3} \ln \mathrm{TS}+\mathrm{TPD} \beta_{4} \ln \mathrm{TP}+\mathrm{TCD} \beta_{5} \ln \mathrm{TC}+\mathrm{EI}$ where:

$\ln \quad=$ Indicates logarithms to base e

Output $=$ Highest achievable production for a specified amount of every input in $\mathrm{kg}$.

TLD = Land intended for cultivation of cotton in acres.

TL $\quad=$ Total labour (Family and hired) utilised, measured in man-days.

TS = Amount of cotton seed used in planting cotton measured in kgs

TP = Amount of pesticides used to cotton measured in bottles (acre packs)

TC = the value of total capital equipment (Agricultural assets) measured in TShs.

TPD = Dummy variable for pesticides ( 1 for farmers used, 0 for farmers not used)

TCD = Dummy variable for capital (1 for famers with capital, 0 for farmers without)

Bi's $\quad=$ represent unidentified parameters to be forecasted.

As reported by Aigner, Chu and Lovell (1977), the error term is considered to be actually a combination of two terms:

$$
E I=V i . ~ U i ; i=1 \ldots N
$$


Whereby

$\mathrm{Vi}=$ stands for identically and independently distributed random errors $\mathrm{N}\left(0, \sigma_{v}^{2}\right)$. These included factors are not under the firm's control.

$\mathrm{Ui}=$ stands for non-negative random variables that identically and independently distributed like $\mathrm{N}\left(0, \sigma_{u}^{2}\right)$ i.e. the Ui distribution is $1 / 2$ normal. The technical efficiency relative to the frontier production function is reflected by $|\mathrm{Ui}|>0$. $|\mathrm{Ui}|=0$ for a plantation of which its products lie on the frontier and $|\mathrm{Ui}|<0$ for a plantation of which its products lie under the frontier.

Bearing in mind that firms are inefficient technically may be not helpful without identification of the sources of the inefficiency (Admassie \& Matambalya, 2002). Therefore, $2^{\text {nd }}$ stage of this evaluation explores the sources of technical inefficiency at the firm level for the sample taken from contract as well as non-contract farmworkers. However, a one-step method has been applied to get estimates of the final maximum likelihood. The model specification for this case is:

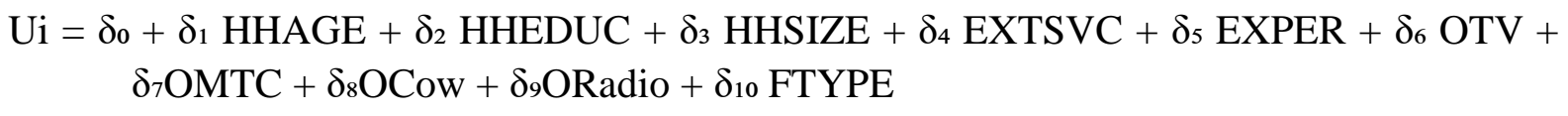

Where

HHAGE $=$ Farmer's age in years

HHEDUC $=$ Farmer's education level in years

HHSIZE $=$ Family/household size taken as total number of family members

FTYPE $=$ Farming type ( 1 for contractual arrangement, 0 for no contract arrangement $)$

EXTSVC $=1$ for farmers who received Extension services, 0 otherwise

EXPER $=$ Farmers experience in cotton cultivation expressed in years

OTV $=1$ for Farmers possessing a TV, 0 otherwise

OMTC $=1$ for farmers possessing motorcycle, 0 otherwise

ORadio $=1$ for Farmers possessing a radio, 0 otherwise

OCow $=1$ for Farmers possessing cows, 0 otherwise

$\delta I$ 's $=$ inefficiency parameters to be estimated

The production's farm-specific technical efficiency, given the amount of inputs, is provided as follows:

$\mathrm{FTE}_{\mathrm{i}}=\exp \left(-\mathrm{U}_{\mathrm{i}}\right)$

The farm-specific technical efficiency lies between 0-1 and also, it is related inversely to the amount of the technical inefficiency. It makes sense to estimate technical efficiency and inefficiency if and only if the data can adequately represent the Cobb Douglas operational form as well as the effects of technical inefficiency, $\mu$, fulfills the specified distributional properties. The operationalisation of the specific model functional form and the distributional 
assumptions were tested by the following hypotheses:

- The null hypothesis that the model used was represented adequately by the appropriate functional form was tested. Results show that translog didn't converge due to Multicollinearity and was rejected. Therefore, the stochastic frontier operational form used is the Cobb Douglas production function.

- The null hypothesis that there is full technical efficiency at all levels in the model $\mathrm{H}_{0}$ : $\lambda=\delta_{0}=\delta_{1}=\ldots \delta_{10}=0$ was rejected due to the fact that the magnitude and significance of estimated value of $\lambda=2.266814$. This implies that a large part of output variation is explained by the model. This result helped to show the appropriateness of employing stochastic frontier model over ordinary least squares. It also reflects the excellent choice and preciseness of the described distributional assumptions of half normal for the estimation of maximum-likelihood of the Cobb Douglas stochastic frontier model

- The null hypothesis that the observed variation in result is due to random effects $\mathrm{H}_{0}$ : $\lambda=0$ was rejected since $\lambda=2.266814$. This has helped to show the dominance of inefficiency component compared to random effect on output variation.

- The null hypothesis that small-holder farmers' characteristics and other institutional factors jointly cannot impact the technical efficiency: $\mathrm{H}_{0}: \delta_{1}=\ldots \delta_{10}=0$ was rejected. That is, since $\lambda>0$, it also implies that the inefficiency component exists in our stochastic production frontier model. Therefore, the null hypothesis that small-holder farmers' characteristics and other factors cannot impact the technical efficiency is strongly denied.

- The null hypothesis that there is no intercept change: $H_{0}: \beta_{1}=\ldots \beta_{5}=0$ was strongly rejected because at least one intercept coefficient is statistically significant distinct from 0 at the levels of $10 \%, 5 \%$ as well as $1 \%$. This result implies that without introducing dummies to some of the common inputs having zeroed observations could have resulted in biased parameter estimates (Battese, 1996).

\section{Research Methodology}

The empirical data for this study relies on cross sectional survey data of household attributes, seed cotton production and marketing collected in Bunda District in September to December, 2014. As reported by the 2002 housing and population census, whereby the population in Bunda District 266,000. The estimated population in each ward was 13,300 while in each village, the estimated population was 2,900 and main occupations included agriculture, livestock and fishing.

According to Aday (1996) in order to estimate a proportion of 50\% for two groups (contract as well as non-contract farmers) having a desired precision of $0.05 \%$, the recommended sample size is 384 respondents. Therefore, sample size of 400 households for survey was sought for this study where 200 contract and 200 non-contract farmer households were planned to be interviewed. The researcher used multistage sampling techniques and started by selecting 6 wards out of 24 that grow cotton purposively. The six wards were selected 


\section{Macrothink}

because they were the ones involved in pilot cotton contract farming. In each of the 6 wards selected, 1 village was purposively selected whereby the final sample was drawn for the same reasons as for the wards.

Since the average household size in Bunda District was 6.8, where each village has an average of 426 households. According to TCB officials during the pilot study, each village had a total of 48 to 80 households that grow cotton out of the total number of 426 households in each village. Therefore, cotton farmers in all the six villages ranged from $288(48 \times 6)$ to 480 (80x6) households. Since the plan was to collect data from 400 cotton farmers, the researcher decided to sample all households involved in cotton farming in all the six villages in order to get the required number of respondents. For that case $100 \%$ of the cotton farmers in villages sampled were included in the survey and this resulted in a total number of 414 households responded to personally administered questionnaire. 220 out of 414 respondents were contract farmer households while 194 out 414 respondents were non-contract farmers. After the examination of data and cleaning, the researcher came out with 400 clean questionnaires for analysis where 211 were for contract farmer households and 189 were for non-contract farmer households.

\section{Results and Discussion}

\subsection{Introduction}

The outcomes of the maximum-likelihood parameter estimate of the stochastic production frontier for cotton are appeared in Table 4.1. The left- hand side of the table contains estimates of out-growers while, on the other hand the right-hand side comprises non out-growers' estimates. The stochastic production frontier model estimated the total number of 18 parameters whereby it involved 11 in the inefficiency model and 7 in the C-D production frontier model. The estimated Six (6) parameters (3 production model and 3 in the efficiency model) were estimated out of the 18 are statistically significantly at 1,5 as well as 10 percent for contract farmers while 5 ( 3 production frontier and 2 in the efficiency model) are statistically significantly at 1,5 as well as 10 percent for non-contract farmers. The forecasted value of the $\lambda$ parameter that is closely linked to with the technical inefficiency variance impacts in the stochastic frontiers is 2.266814. These outcomes recommend insinuate that the effects of technical inefficiency are important element of the aggregate variableness of cotton production for the sample farmworkers (Battese \& Coelli, 1995). 


\section{$\triangle$ Macrothink}

Journal of Public Administration and Governance ISSN 2161-7104

Table 4.1. Maximum likelihood estimates for the parameters of the Cobb-Douglas stochastic frontier production function for contract and non-contract farmers

\begin{tabular}{|c|c|c|c|c|c|c|c|c|c|}
\hline \multicolumn{5}{|c|}{ Contract farmers $\mathrm{N}=\mathbf{2 1 1}$} & \multicolumn{5}{|c|}{ Non-contract farmers $N=189$} \\
\hline Lnoutput & Coef. & Std. Err. & Z & $\mathrm{P}>\mathrm{Z}$ & Lnoutput & Coef. & Std. Err. & $\mathrm{Z}$ & $\mathrm{P}>\mathrm{z}$ \\
\hline Lntld & -.0849264 & .2284298 & -0.37 & 0.710 & Lntld & .6832572 & 2687693 & 2.54 & 0.011 \\
\hline Lnts & .3775678 & .1767694 & 2.14 & 0.033 & Lnts & .1082134 & .2338563 & 0.46 & 0.644 \\
\hline Lntp & .5252666 & .1391579 & 3.77 & 0.000 & Lntp & .2500386 & .1200905 & 2.08 & 0.037 \\
\hline Tpd & 1.570517 & .4768626 & 3.29 & 0.001 & Tpd & .4580613 & .3798523 & 1.21 & 0.228 \\
\hline Lntca & .0914185 & .0302951 & 3.02 & 0.003 & Lntca & -.005612 & .031993 & -0.18 & 0.861 \\
\hline Tcad & .5825944 & .4137419 & 1.41 & 0.159 & Tcad & -.5031585 & .4256994 & -1.18 & 0.237 \\
\hline Lntl & .0982829 & .0760005 & 1.29 & 0.196 & Lntl & .1699715 & .0993513 & 1.71 & 0.087 \\
\hline _cons & 3.41271 & .5979671 & 5.71 & 0.000 & _cons & 4.617803 & .6734301 & 6.86 & 0.000 \\
\hline _cons & -1.01919 & 2452413 & -4.16 & 0.000 & _cons & -1.509474 & 4072162 & -3.71 & 0.000 \\
\hline
\end{tabular}

\subsection{Production Frontier and Technical Efficiency Estimates}

When it comes to estimates of Maximum Likelihood for inputs of production as presented in Table 4.1 above, the forecasted Maximum-Likelihood land coefficient under cotton cultivation indicated negative value of 0.0849 for contract farmers that was not significant and a positive value of 0.6832572 for non-contract farmers that were significant at $1 \%$. Thus, an extension of farm area (land) under cotton cultivations by $1 \%$ would raise production of non-contract farmers at $6.83 \%$ while for contract farmers no clear evidence can be provided concerning the effects of land on the outputs because it is not significant.

The forecasted coefficient for capital showed a positive value of 0.0914185 for contract farmers and is significant at $5 \%$ while for non-contract farmers it shows a negative value of 0.0056 which is not significant. Therefore, an increase of capital by 1 percent would increase the output of contract farmers by $0.914 \%$ while no clear evidence can be provided on the effects of capital on the outputs of non-contract farmers.

The forecasted coefficients for total labor (hired and family labor) indicated a positive value of 0.0983 for contract farmers, but not significant while showed positive value of 0.1699 for non-contract farmers and it was significant at $10 \%$. Therefore, no clear evidence can be provided concerning the effects of labor on contract farmers while one percent increase of labour on non-contract farmers will boost output of production by $1.699 \%$.

The forecasted coefficient for total seed used in cotton cultivation showed a positive value of 0.3776 for contract farmers and was significant at $5 \%$ while showed positive value of 0.1082 for non-contract farmers and was not significant. Therefore, $1 \%$ of increased cotton seed would simultaneously result into increment of contract farmers production volume by $3.776 \%$ while no clear evidence can be provided concerning the impact of seed on non-contract farmers production volume. 


\section{I Macrothink}

Journal of Public Administration and Governance

ISSN 2161-7104

2021, Vol. 11, No. 2

The forecasted coefficient for pesticides showed a favorable outcome of 0.5253 for contract farmers and was significant at $1 \%$ while it showed positive value of 0.2500 for non-contract farmers and it was significant at $5 \%$. Therefore $1 \%$ increase in pesticides would increase the contract farmers' output by $5.253 \%$ while for non-contract farmers; increment of one percent of pesticides will increase the output of non-contract farmers by 2.5 percent.

\subsection{Sources of Technical Inefficiency of Contract and Non-Contract Farmers}

The efficiency analysis outcomes showed that sample scores of contract farmers, varied from $1.75 \%$ to $87.07 \%$ (average 46.05 ). This implies that cotton farming has significant technical inefficiency. This outcomes' major implication is that cotton-farmers may cut down their production inputs by approximately $53.95 \%$ without reduction of their output, easily by technical efficiency improvements. As a result, this can boost the gross margin as well as minimize costs of production on cotton crop. This means that, on average small-holder cotton contract farmers in the study area incurred about 53.95 percent loss in output due to technical inefficiency. This implies that on average output can be increased by at least $53.95 \%$ while utilising existing resources and technology if inefficiency factors are fully addressed.

On the other hand, the technical efficiencies of small-holder non-contract farmers ranged from $3.94 \%$ to $82.05 \%$ with a mean of $46.79 \%$. That is to say, in this study area on average small-holder non-contract farmers incurred around $53.21 \%$ loss in production output because of technical inefficiencies. This means that on average output may be boosted by at least $53.21 \%$ when utilizing current technology and resources provided that factors of inefficiency are fully taken into account. Frequency analysis of technical efficiency scores revealed that 92 out of farmers' sample of 400 (equivalent to 23\%) had a technical efficiency score below $30 \%, 121$ out of 400 of the sample farmers (equivalent to $30.25 \%$ possessed technical efficiency between $30 \%$ and $50 \%$, whereas 137 of farmers (equivalent to $34.25 \%$ ) possessed a level of technical efficiency level between 50 and $70 \%$. The rest which is 50 out of 400 farmers (equivalent to 12.5\%) had a technical efficiency level of 70 to $87.069 \%$ (see Figure 4.1).

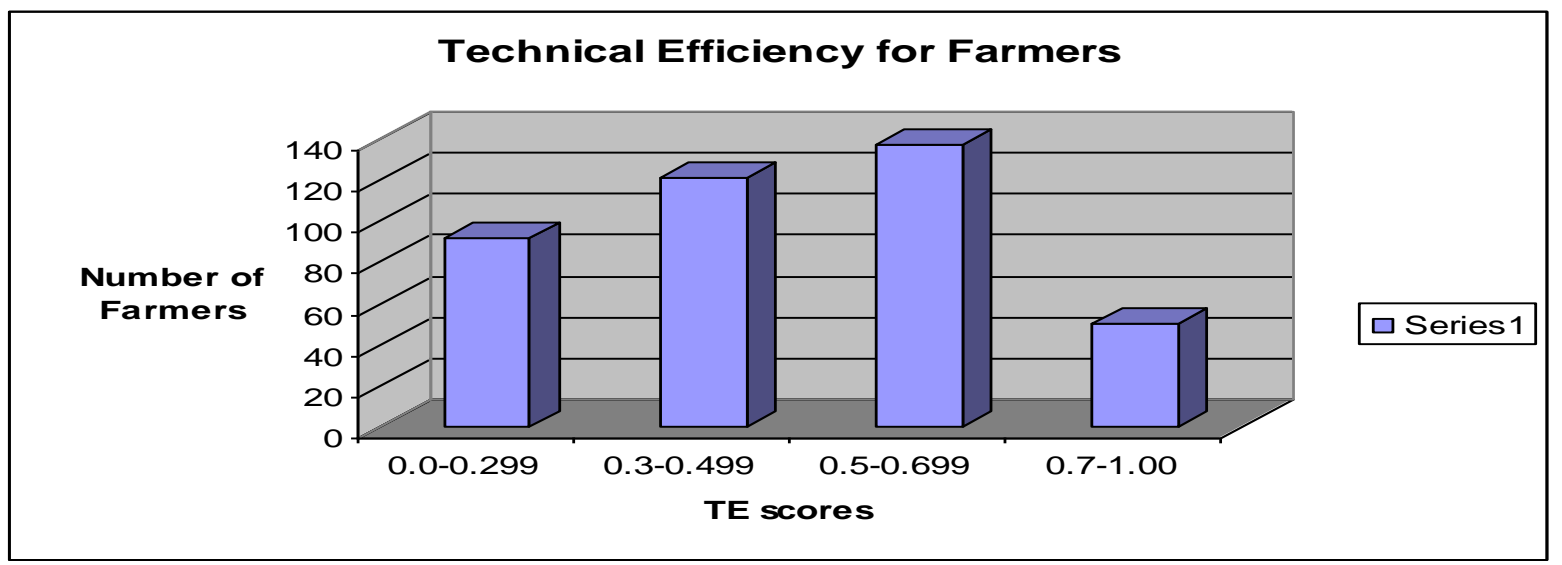

Figure 4.1. Bar chart representation of Technical Efficiency Sc ore distribution

The forecasted coefficients in the inefficiency models are depicted in Table 4.2. These results 
concur with results of previous studies done by Otsuki (2010) as well as Amaza and Maurice (2005). Otsuki (2010) found that the technical efficiency measure descriptive statistics possessed a mean of 0.458 as well as standard error of 0.206 , with a minimum of 0.009 , and maximum of 0.851. Amaza and Maurice (2005) examined the technical efficiency influencing factors of rice-based production chains in association with farmers in the State of Adamawa. A Stochastic Frontier Analysis was employed on a cross-sectional data set included 122 farmworkers gathered during the period of 2002/2003. The outcomes revealed that the levels of relative technical efficiency vary considerably between plantations with a range between 0.026 and 0.97 and as well as 0.48 mean of technical efficiency.

Table 4.2. Coefficients of inefficiency model for contract and non-contract farmers

\begin{tabular}{|c|c|c|c|c|c|c|c|c|c|}
\hline \multicolumn{5}{|c|}{ Contract farmers $\mathbf{N}=\mathbf{2 1 1}$} & \multicolumn{5}{|c|}{ Non-contract farmers $\mathrm{N}=\mathbf{1 8 9}$} \\
\hline & Coef. & Std. Err. & $\mathrm{Z}$ & $\mathrm{P}>\mathrm{z}$ & & Coef. & Std. Err. & $\mathrm{Z}$ & $\mathrm{P}>\mathrm{z}$ \\
\hline Exper & .0255414 & .0141685 & 1.80 & 0.071 & Exper & .0140647 & .013191 & 1.07 & 0.286 \\
\hline Hhsize & .012383 & .0617261 & 0.20 & 0.841 & Hhsize & -.0171391 & .0586659 & -0.29 & 0.770 \\
\hline Hhsex & 1.90946 & 1.148635 & 1.66 & 0.096 & Hhsex & .1181995 & .3924296 & 0.30 & 0.763 \\
\hline Hhage & .0086405 & .0123145 & 0.70 & 0.483 & Hhage & .0039107 & .0133276 & 0.29 & 0.769 \\
\hline Hheduc & -.6228995 & .6586422 & -0.95 & 0.344 & Hheduc & .8752814 & .7214701 & 1.21 & 0.225 \\
\hline Extsve & -.0450056 & .2667453 & -0.17 & 0.866 & Extsvc & .3015545 & .3646315 & 0.83 & 0.408 \\
\hline Mcycle & -.001229 & .2672743 & -0.00 & 0.996 & Mcycle & -.0216631 & .2567898 & -0.08 & 0.933 \\
\hline Cow & -.0618406 & .2801888 & -0.22 & 0.825 & Cow & -.5430013 & .2884629 & -1.88 & 0.060 \\
\hline $\mathrm{Tv}$ & .8274426 & .375519 & 2.20 & 0.028 & $\mathrm{Tv}$ & 1.034297 & .5185379 & 1.99 & 0.046 \\
\hline Radio & -.3181568 & .4045596 & -0.79 & 0.432 & Radio & -.3628252 & .3593022 & -1.01 & 0.313 \\
\hline _cons & -1.464383 & 1.371869 & -1.07 & 0.286 & cons & -.510625 & .9512417 & -0.54 & 0.591 \\
\hline sigma_v & .600739 & .073663 & & .4724011 & sigma_v & .4701341 & .0957231 & & .3154353 \\
\hline
\end{tabular}

NB: Stochastic frontier normal/half-normal model, Number of obs $=211$, Wald chi2 (17) $=$ 162.00, Log likelihood $=-284.88582$, Prob $>$ chi2 $=0.0000$ for contract farmers and the Stochastic frontier normal/half-normal model, Number of obs $=189$, Wald chi2 (7) $=$ 179.35, Log likelihood $=-227.77244$, Prob $>$ chi2 $=0.0000$ for non-contract farmers

Looking on the separate sources of inefficiencies between contract and non-contract farmers (See Table 4.2 above), it must be emphasized that as long as the explained variable in the inefficiency function is the mode of inefficiency, a parameter's positive sign shows that the related variable possesses an adverse impact on efficiency and a positive efficiency impact is indicated by negative sign.

The Experience coefficient of contract farmers appeared to be positive $(0.255414)$ and significant at $0.07(\mathrm{P}<0.10)$. This shows that young farmworkers were more efficient than experienced ones. This could be because cotton cultivation in contract farming might need physical skill that is much more challenging, hence providing advantage to the young 
farmworkers over old farmworkers who depend on the practice of traditional farming; as a result they fail to cope with requirement of modern technology. It could also be because most of the younger cotton farmers easily adopt the requirement of contract farming compared to long experienced farmers. This finding supports the outcomes of earlier investigations undertaken by Battese and Coelli (1995) and Mathijs and Vranken (2000). The positive forecast for the farmers' experience suggested that the period of years in cotton production resulted in improved management capabilities being attained for many years by old farmworkers which were useful in contract farming. This means that cotton contract farming does not extremely rely on the farmers' experience but rely on new ways of farm management.

Also, the coefficient of head of household was positive and significant at $10 \%$ for contract farmers. This shows that as households headed by male are not efficient compared to households headed by female. This could be interpreted by reason of the fact that female-headed household exert more efforts in producing seed cotton in the study area so that during the marketing season they may repay the input loan and have an access for personal use. Male household heads are very reluctant and not afraid of repaying their input loan. The hypothesis that farms with high women's' participations were less efficient was not supported by the positive and significant coefficient. This result was in line with the findings of Mathijs and Vranken (2000) and Zavela et al., (2005).

In addition, the TV coefficient for contract farmers was positive as well as significant at 5 percent. The unexpected sign of household having coefficient of Television indicates that as the family members increase in watching programs not related to cotton production, farmers become inefficient. This might be because majority of family members are either wasting much time in watching various TV programs instead of concentrating in cotton farms management or watch TV programs that do not add value in terms of getting extension services that could help them improve farm management. This does not support the study done by Pornpratansombat, Bauer and Boland (2011) who found that Information relating to organic-rice farming is particularly significant for the farmworkers to improve their farming knowledge, transform their farming practices as well as to improve the situation of their production and market. About $60 \%$ of organic-rice farmers have managed to get information from the government and NGOs agents (extension agents), through meeting of the group, $18 \%$ of organic-farms received information from their close farmworkers (friends and relatives), while about $14 \%$ is taken by mass media (radio and television).

For the case of non-contract farmers, two variables in the inefficiency model were significant which were: owning Cow and TV coefficients. The coefficient of owning cows appeared to be negative as well as significant at $10 \%(\mathrm{p}<0.10)$. This means that farmworkers owning cows perform better compared with farmers not owning cows. This might be true because non-contract farmers owning cows use oxen in tilling the land and become more cost-effective than non-contract farmers without cows and merely use hand hoe or have to hire oxen driven ploughs from other farmers. But experience shows that, farmers owning oxen will only hire out if they have completed cultivating their own plots. 


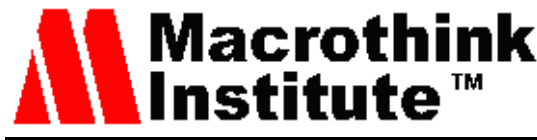

The TV coefficient for non-contract farmers appeared to be positive and significant at $5 \%$ as for the case of contract farmers. The unexpected sign of coefficient of non-contract farmers having TV indicates that as the family members increase in watching TV programs not related to cotton production, farmers become inefficient. This might be so due to the fact that majority of family members are either wasting much time in watching various TV programs instead of going to cotton farms for production or watch TV programs that do not add value in terms of getting extension services that could help them improve farm management as for the case of contract farmers. This study does not support the study done by Pornpratansombat, Bauer and Boland (2011) as cited for the contract farmers' case.

Since the technical efficiencies of contract and non-contract farmers were so close, therefore, in order to find out if there existed any significant difference between these groups, a t-test was performed and finally, the results showed that there was no significant difference between the technical efficiency of contract and non-contract farmers (see Table 4.3). This implies that contractual arrangement didn't motivate contract farmers to exert more efforts in order to increase efficiency that could result into high productivity.

Table 4.3. Two-sample $t$ test with equal variances for contract and non contract farmers

\begin{tabular}{|l|l|l|l|l|l|l|}
\hline \hline Group & Obs & Mean & Std. Err. & Std. Dev. & {$[$ 95\% Conf. } & Interval] \\
\hline Non-contract farmers (0) & 189 & .4678637 & .0142823 & .1963493 & .4396896 & .4960379 \\
Contract farmers (1) & 211 & .4604633 & .0142808 & .2074409 & .4323111 & .4886154 \\
Combined & 400 & .46396 & .0101029 & .2020577 & .4440985 & .4838215 \\
Diff & & .0074005 & .0202584 & & -.0324264 & .0472273 \\
\hline
\end{tabular}

$\operatorname{diff}=\operatorname{mean}(0)-\operatorname{mean}(1)$

Ho: $\operatorname{diff}=0$

Ha: diff $<0$

$\operatorname{Pr}(\mathrm{T}<\mathrm{t})=0.6425$

$$
\begin{gathered}
t=0.3653 \\
\text { degrees of freedom }=
\end{gathered}
$$

Some of the issues that didn't motivate contract farmer to increase efficiency in seed cotton production include; First, in 2011/2012 season the total cost of input loan given to contract farmers was too low equivalent to only TShs. 7,600/= per acre, but the actual cost of cotton production from land preparation, cultivating, sowing, thinning, weeding, pest control/spraying, harvesting up to transportation to the buying centre was approximately 237,700 to $267,700 /=$ per acre, Secondly, there was poor enforcement and penalty mechanism to contract defaulters. Contract farmers and ginners were not taken any measures in case they fail to fulfil their contract obligations, third, farmers who were not in contract farming were sometimes enjoying higher prices from roaming and unauthorized cotton buyers compared to contract farmers and lastly, although Section 14 of the contract required buyers to provide extension services, it was not clear when and how many times should buyers provide extension services to Farmers Business Groups. Only government Agricultural Extension 
Officers provided extension services to all farmers whether they are in contract or not.

\section{Conclusion and Policy Implication}

\subsection{Conclusion}

The goals of the study focused on analyzing the technical efficiency of contract as well as non-contract farmers and identify the sources of inefficiency. The outcomes of efficiency analysis show that small-holder farmers were producing at the lower levels, as if this was not enough they also operated comparatively a long way from the production frontier. Therefore, there was ample room to improve productivity and output through boosting efficiency of production at the relatively unproductive farms as well as maintaining the effectiveness of the farmers working in or near to the frontier. As pointed out earlier in the above section, the combined mean technical efficiency of all farmers whether they were in contract or not was found to be 46.40 with a minimum of $1.75 \%$ and a maximum of $87.07 \%$. This shows that in general, all farmers incurred loss of about $53.60 \%$ loss in output due to technical inefficiency

\subsection{Policy Implication}

First, younger farmers needed to be encouraged to join contract farming in order to get high productivity. Also, older farmers should be advised to do away with their traditional farming practice and adopt the new techniques given by extension officers. Moreover, older farmers need to be encouraged to collaborate with younger farmers for more effective production and contractual skills at an early stage that could help them manage cotton farms properly.

Secondly, more female headed households should be encouraged to participate in contract farming in Tanzania. Otherwise, the decision to join contract farming must not be left to male alone in the families but must be decided by involving female family members within the household level so that cotton farming activities at the end should be handled jointly by both male and female in order to increase productivity.

Thirdly, both contract and non-contract farmers should watch TV programs which are educative and can assist them gain farm management knowledge that can help increase productivity. Also, TV/Radio programs pioneered by TCB which show various techniques on proper cotton production should be revived and reinstated in order to serve as a means of providing extension services to farmers.

Fourth, in order to motivate farmers to exert more effort in order to increase productivity, ginners are required to provide more services in exchange of exclusive purchasing rights as agreed when signing contracts, buy seed cotton from contract farmers at a market price or higher than market price, pay premium price to farmers produced high quality seed cotton and provide extension services as agreed during contract signing. Furthermore, price signals can be used by ginners to motivate farmers to spend more time in cotton farm management in order to increase productivity while instructions can be used in coordinating production of high quality seed cotton. Enforcement mechanism should well be stated in the contract and strong measures should be taken again defaulters. 


\section{References}

Abri, A. G., \& Mahmoudzadeh, M. (2015). Impact of information technology on productivity and efficiency in Iranian manufacturing industries. Journal of industrial engineering international, 11(1), 143-157. https://doi.org/10.1007/s40092-014-0095-1

Aday, L. (1996) Designing and Conducting Health Surveys, San Francisco: Jossey-Bass.

Aigner, D., Lovell, C. K., \& Schmidt, P. (1977). Formulation and estimation of stochastic frontier production function models. Journal of econometrics, 6(1), 21-37. https://doi.org/10.1016/0304-4076(77)90052-5

Amaza, P. S., \& Maurice, D. C. (2005). Identification of factors that influence technical efficiency in rice-based production systems in Nigeria. Paper presented at Workshop on Policies and Strategies for Promoting Rice Production and Food Security in Sub-Saharan Africa:- November 2005, Cotonou (Benin), pp. 7-9

Battese, G. E., \& Coelli, T. J. (1995). A model for technical inefficiency effects in a stochastic frontier production function for panel data. Empirical economics, 20(2), 325-332. https://doi.org/10.1007/BF01205442

Battese, G. E., Rao, D. P., \& O'donnell, C. J. (2004). A metafrontier production function for estimation of technical efficiencies and technology gaps for firms operating under different technologies. Journal of productivity analysis, 21(1), 91-103. https://doi.org/10.1023/B:PROD.0000012454.06094.29

Binam, J. N., Tonye, J., \& Wandji, N. (2005). Source of technical efficiency among smallholder maize and peanut farmers in the slash and burn agriculture zone of Cameroon. Journal of economic cooperation, 26(1), 193-210.

Bui, T. L., Tran, H. C., Azadi, H., \& Lebailly, P. (2018). Improving the technical efficiency of Sengcu rice producers through better financial management and sustainable farming practices in mountainous areas of Vietnam. Sustainability, 10(7), 2279.

Dorward, A., \& Chirwa, E. (2014). The rehabilitation of agricultural input subsidies. IIED Working Paper.

Gul, M., Koc, B., Dagistan, E., Akpinar, M. G., \& Parlakay, O. (2009). Determination of technical efficiency in cotton growing farms in Turkey: A case study of Cukurova region. African journal of Agricultural research, 4(10), 944-949.

Hayami, Y., \& Ruttan, V. W. (1971). Agricultural development: an international perspective. Baltimore, Md/London: The Johns Hopkins Press.

Kumbhakar, S. C., \& Lovell, C. A. K. (2000). Stochastic Frontier Analysis. Cambridge University Press, Cambridge. https://doi.org/10.1017/CBO9781139174411

Masakure, O., \& Henson, S. (2005). Why do small-scale producers choose to produce under contract? Lessons from nontraditional vegetable exports from Zimbabwe. World Development, 33(10), 1721-1733. https://doi.org/10.1016/j.worlddev.2005.04.016 


\section{Macrothink}

Journal of Public Administration and Governance ISSN 2161-7104

Mathijs, E., \& Vranken, L. (2000). Farm restructuring and efficiency in transition: Evidence from Bulgaria and Hungary (No. 372-2016-19364).

Mburu, S., Ackello-Ogutu, C., \& Mulwa, R. (2014). Analysis of economic efficiency and farm size: A case study of wheat farmers in Nakuru District, Kenya. Economics Research International, 2014. https://doi.org/10.1155/2014/802706

Meeusen, W., \& van Den Broeck, J. (1977). Efficiency estimation from Cobb-Douglas production functions with composed error. International economic review, 18(2), 435-444. https://doi.org/10.2307/2525757

Michelson, H., Reardon, T., \& Perez, F. (2012). Small farmers and big retail: trade-offs of supplying supermarkets in Nicaragua. World Development, 40(2), 342-354. https://doi.org/10.1016/j.worlddev.2011.07.013

Msuya, E. \&Ashimogo, G. (2005). Estimation of Technical Efficiency in Tanzanian Sugarcane Production: A Case Study of Mtibwa Sugar Estate Outgrowers Scheme. Available Online at http://mpra.ub.uni-muenchen.de/3747/ MPRA Paper No. 3747, posted 07. November 2007 / 03:26 accessed on 20/12/2011.

Msuya,E, Hisano, S and Nariu,T., (2008). An Analysis of Technical Efficiency of Smallholder Maize Farmers in Tanzania in the Globalization Era. Paper presented in the XII World Congress of Rural Sociology of the International Rural Sociology Association, Goyang, Korea 2008.

Ngugi, I. K., Gitau, R., \& Nyoro, J. (2007). Access to high value markets by smallholder farmers of African indigenous vegetables in Kenya. Regoverning markets innovative practice series, IIED, London.

O’Donnell, C. J., Rao, D. P., \& Battese, G. E. (2008). Metafrontier frameworks for the study of firm-level efficiencies and technology ratios. Empirical economics, 34(2), 231-255. https://doi.org/10.1007/s00181-007-0119-4

Otsuki, T. (2010). Estimating Agroforestry's Effect on Productivity in Kenya: An Application of a Treatment Effects Model. OSIPP Discussion Paper: DP-2010-E-001

Pornpratansombat, P., Bauer, B., \& Boland, H. (2011). The adoption of organic rice farming in Northeastern Thailand. Journal of Organic Systems, 6(3), 4-12.

Poudel, K. L., et al, (2011). Comparing technical efficiency of organic and conventional coffee farms in Nepal using data envelopment analysis (DEA) approach. 85th Annual Conference of the Agricultural Economics Society Warwick University, Vol.18 No. 20 April 2011

Rao, E. J., \& Qaim, M. (2011). Supermarkets, farm household income, and poverty: insights from Kenya. World Development, 384-796. https://doi.org/10.1016/j.worlddev.2010.09.005

Roco, L., Bravo-Ureta, B., Engler, A., \& Jara-Rojas, R. (2017). The impact of climatic 
change adaptation on agricultural productivity in Central Chile: A stochastic production frontier approach. Sustainability, 9(9), 1648. https://doi.org/10.3390/su9091648

TCB. (2010a). Tanzania Cotton Board -Annual Report and Accounts for the year ending on 30th June 2010.

Thiam, A., Bravo-Ureta, B. E., \& Rivas, T. E. (2001). Technical efficiency in developing country agriculture: a meta-analysis. Agricultural economics, 25(2-3), 235-243. https://doi.org/10.1111/j.1574-0862.2001.tb00204.x

Ullah, A., Khan, D., \& Zheng, S. (2017). The determinants of technical efficiency of peach growers: evidence from Khyber Pakhtunkhwa, Pakistan. Custos e Agronegocio On Line, 13(4), 211-238.

URT, (2016) Agricultural Sector Development Programme report two (ASDP II), Government Programme Document May 2016

Zepeda, L. (2001). Agricultural investment, production capacity and productivity. FAO Economic and Social Development Paper, 3-20.

\section{Copyright Disclaimer}

Copyright for this article is retained by the author(s), with first publication rights granted to the journal.

This is an open-access article distributed under the terms and conditions of the Creative Commons Attribution license (http://creativecommons.org/licenses/by/4.0/). 